\title{
Schools overcoming the digital divide: in depth analyses towards organizational resilience in the computer and information literacy domain
}

\author{
Kerstin Drossel ${ }^{*}$, Birgit Eickelmann and Mario Vennemann
}

${ }^{*}$ Correspondence:

Kdrossel@mail.upb.de

Paderborn University,

Institute for Educational

Research, Warburger Straße

100, 33098 Paderborn,

Germany

\begin{abstract}
Background: The ongoing digitalization poses new challenges for schools concerning students' digital skills. In this context, the International Computer and Information Literacy Study (IEA-ICILS 2018) has identified substantial social disparities concerning computer and information literacy of grade 8 students. Furthermore, it has been observed that many schools, especially those located in socioeconomically challenged areas, are particularly engaged in supporting students' digital literacy and innovatively designing learning processes with information and communications technology (ICT). Empirical studies have made it apparent that some schools have high average achievements concerning domains such as reading literacy and mathematics in spite of socioeconomically challenged student bodies. These schools are regarded as being organizationally resilient. This contribution focusses on these organizationally resilient schools with regard to the domain of computer and information literacy. It aims to investigate how these schools can be classified as a typology according to selected school and/or teacher characteristics.
\end{abstract}

Methods: As a first step, representative samples of IEA-ICILS 2018 are used to identify organizationally resilient schools by using students' achievement measures (plausible values) and their background information regarding their families' socio-economic status. In order to develop a typology, latent profile analyses (LPA) are conducted by using input and process indicators on the school level, which have been proven to be relevant for implementation through existing empirical research.

Results: About one twentieth of the schools examined in this contribution can be regarded as organizationally resilient and can be allocated onto a typology of three school types that are characterized by different school-level factors.

Conclusions: The international comparison permits the conclusion that the phenomenon of organizational resilience is also existent with regard to the content domain of computer and information literacy. However, the proportion of resilient schools is subject to considerable variation between countries. 
Keywords: IEA-ICILS 2018, Organisational resilience, Computer and information literacy, School effectiveness, School improvement in the digital age, secondary schools

\section{Introduction: The relevance of the school context for a successful implementation of ICT in schools}

The ongoing digitalization of various aspects of society currently creates numerous challenges for schools worldwide (Voogt et al. 2013, 2018). Consequently, demands focus on the creation of new forms of teaching and learning (cf. Mishra and Mehta 2017) in order to exploit the positive potentials of information and communication technology (ICT). Fostering students' digital literacy is regarded as tremendously relevant for enabling students to cope with future educational, professional, and private endeavours (Geisinger 2016; Ottestad and Gudmundsdottir 2018), for ensuring social equity (Eickelmann 2018), and for closing existing achievement gaps in this domain (cf. van Deursen and van Dijk 2018). In this context, many national and/or international initiatives have been developed in recent years which emphasize the future importance of being able to use ICT in a reflected and secure manner (Ferrari 2012; Olszewski and Crompton 2020). For instance, the European Commission outlines that information and data literacy, communication and collaboration, digital content creation, safety and problem solving are digital competences that every citizen must have to be able to participate effectively in 21st century societies (Digital Competence Framework for Citizens [DigComp 2.1], cf. Carretero et al. 2017). Furthermore, researchers, policy-makers, and educational stakeholders in general are discussing the question of what makes school systems effective in this domain (such as "World class" cf. Schleicher 2018) and how achievement gaps, which put students from socioeconomically or culturally less privileged families at a disadvantage, can be prevented (European Commission 2020; OECD 2010).

The International Computer and Information Literacy Study (IEA-ICILS 2018) contributed to the current international discourse by revealing that less than a quarter of the assessed eighth-grade students reached the top two of the five achievement benchmarks. Consequently, researchers concluded that a substantial portion of secondary school students does not have the computer-related competencies to successfully participate in society (cf. Fraillon et al. 2019a). Not least against this background, UNESCO (2017) included the ICILS study in its educational monitoring (sustainable development goal 4.4: "By 2030, substantially increase the number of youth and adults who have relevant skills, including technical and vocational skills, for employment, decent work and entrepreneurship").

In addition, it was empirically demonstrated by means of a computer-based assessment of students' computer and information literacy (CIL) that this interdisciplinary key competence is also affected by partly substantial social disparities (Eickelmann et al. cf. 2019; Fraillon et al. 2019a; Senkbeil et al. 2019). In Germany for instance, students from less privileged social backgrounds on average scored about 50 points lower on the CIL achievement scale than their counterparts from socioeconomically and/or culturally more affluent families (cf. Ercikan et al. 2018; Fraillon et al. 2014, 2019a; Fraillon 2018; Senkbeil et al. 2019). Although these results vary depending on how the social background is operationalized, the pattern of substantial achievement 
gaps relating to students' cultural or socioeconomic background can be observed in every participating educational system of IEA-ICILS 2018 (Fraillon et al. 2019a). However, by focusing on averages of such disparities, it was not acknowledged in IEA-ICILS 2018-neither on national nor on international level-that there are several participating educational systems and/or schools in the IEA-ICILS 2018 sample that started to promote students' competent and reflective use of ICT years ago; and did so independently of their student bodies' socioeconomic composition.

In relation to teaching and learning with ICT, as in other more curricular domains (such as reading, mathematics, or science), researchers assume that the particular school is the unit of action in which teaching and learning with ICT should be promoted and students' CIL should be improved (Tondeur et al. 2008). Despite this assumption, which is theoretically and empirically supported by school effectiveness research (SER) and of tremendous relevance for school development in the digital age, the approach of regarding the school level as a central unit of action for fostering students' CIL has only been pursued to a limited extend by national and international empirical educational research. From the perspective of school development research and in the light of the outlined research findings on social disparities in IEAICILS 2018, the schools where students-despite their challenging socioeconomic or social student body composition-achieve a high average level of CIL appear to be of importance in the context of teaching CIL. These schools are described as being organizationally resilient in the literature of the field of teaching and learning (Schelvis et al. 2014).

Due to this perception of the relevance of the school level, empirical research already focused on the phenomenon of the organizational resilience of schools in other domains (such as reading, mathematics, or science) and indicates that resilient schools have both specific characteristics and distinctive leadership (Muijs et al. 2004). For the domain of CIL, corresponding findings are only available for some countries with data from ICILS 2013 (Eickelmann et al. 2019). The authors determined four types of resilient schools on the basis of schools which, despite the socially disadvantaged situation of pupils, displayed a high level of computer-related skills in the ICILS 2013 study. The four types were classified into "competent schools", "restrained schools", "pragmatic schools", and "pioneer schools". One-fifth of the teachers in the resilient schools values their own digital literacy very highly and reported sufficient availability of ICT resources. Furthermore, the research found that the actions of the principals vary according to the identified type of school. Especially in the "competent schools" this is very pronounced with regard to the integration of digital media.

In summary, only a limited amount of existing research literature in the field focuses on school characteristics related to the successful teaching of CIL. Findings on the current situation are not available. This paper therefore aims to close this research gap. From a methodological perspective, it should be emphasized, that the existing empirical findings mostly rely on multi-level modelling and therefore neglect similarities of schools in the sense of a school typology (cf. Hatlevik et al. 2015; Meggiolaro 2018). For that reason, an alternative methodological approach-a structure-detecting methodwas chosen for this paper (cf. "Determining a typology of organizationally resilient schools in IEA-ICILS 2018” section). 
In the light of the identified research gap and its relevance for both educational research and school improvement, the first step is to answer the question of whether the phenomenon of the organizational resilience of schools can also be observed in the area of CIL with current data. As a second step, whether the identified schools can be allocated to a typology of schools that share common school characteristics, as indicated by Muijs et al. (2004) will be investigated. Moreover, it will be analyzed how the types are distributed in each of the participating countries and benchmarking participants of IEA-ICILS 2018.

In order to answer these research questions for different cultural contexts, this secondary analyses of the IEA-ICILS 2018 data will cover all participating countries and benchmark participants. This could make it possible to learn from other education systems through international comparisons (Torney-Purta and Amadeo 2013).

Due to its relevance for the research interests, the contextual framework of the study IEA-ICILS 2018 will be presented in the following "The contextual framework of IEA-ICILS 2018" section. Subsequently, the state of research on the school characteristics which is used in this paper to typify the organizationally resilient schools in IEAICILS 2018 will be presented ("Review of relevant literature and research questions" section). These include characteristics, which other studies identified as important for school development with ICT. Apart from the availability of ICT and the frequency of ICT use, these include characteristics such as the individual competence reports of teachers and the attitude of the teaching staff towards the potentials of ICT for teaching and learning. In order to assure transparency, we focus on the methodological procedures used in this contribution in the subsequent section ("Data and methodology" section). Following the presentation of the analysis results ("Results: identification and description of organizational resilient schools in the digital age" section), the findings will be discussed in terms of content and methodology ("Discussion" section).

\section{The contextual framework of IEA-ICILS 2018}

In the sense of a dynamic literacy approach (cf. Ainley et al. 2016), Fraillon et al. (2014) define CIL according to in IEA-ICILS 2013 as an: "individual's ability to use computers to investigate, create, and communicate in order to participate effectively at home, at school, in the workplace, and in the community" (p. 5). The contextual framework for the acquisition of CIL in IEA-ICILS 2018 draws on an input-process-output model for school learning (cf. Fraillon et al. 2019b) by categorizing relevant factors on different levels of school education (such as the individual and school or class level), and therefore acknowledges the multi-level nature of school education. Further, it systematically builds on findings and assumptions from previous SER models aimed at conceptualizing the relationship between input and process variables as well as educational outcomes (Creemers and Kyriakides 2006; De Jong et al. 2004; Scheerens 1990; Scheerens and Bosker 1997).

The contextual framework of IEA-ICILS 2018 distinguishes between antecedents (or inputs) and processes and differentiates between four different levels: (1) level of the wider community, (2) school and classroom level, (3) the student level, and (4) the level of the home environment. In order to explain the students' CIL (outcome), it is necessary to put a combined focus on both antecedents and the processes as a whole. In the model, 
the antecedents are expected to have an indirect effect on student achievement, while the process factors are expected to have a direct effect on students' CIL achievement. The following paragraphs briefly describe the four levels of the contextual model in IEAICILS 2018 (for further details see Fraillon et al. 2019b).

The level of the wider community refers to the antecedents for the acquisition of CIL; for instance, structural aspects of the respective educational system. Technology-related strategies, the curriculum, and other system-specific objectives are regarded as relevant process variables on this level.

The school and classroom level refers to school-and class-related antecedents, such as the availability of ICT, principals' leadership, or teachers' use of ICT.

At the student level students' age, gender, and educational aspirations are the most relevant individual antecedents for the acquisition of CIL. With regard to the assumed process variables, aspects of attitude (e.g. ICT-related self-efficacy) and/or behaviour (e.g. use of ICT) have a direct effect on students' CIL achievement (ibid.).

At the level of home environment, the family's background characteristics are of particular interest. This level refers to the family-specific antecedents such as the family's socioeconomic status (SES) and/or their immigrant status. In contrast, the use of ICT at home and the communication with family members about ICT are considered as relevant process indicators for the acquisition of CIL (cf. Eickelmann et al. 2019).

Besides the predictors considered in the international framework, further factors were identified as relevant for the acquisition of CIL. These include, for example, aspects of teacher cooperation (cf. Drossel and Eickelmann 2017).

Following the assumptions of the presented contextual framework, this paper focuses on the factors on school level. Since individual background characteristics of the students are also considered, this paper also tackles the individual level and, with means of an international comparison, also the level of the wider community.

\section{Review of relevant literature and research questions}

Given the lack of research on the organizational resilience of schools in the domain of CIL, the following section will summarize recent research findings on those factors on school level that have proven to be important for the successful implementation of ICT in teaching and learning as well as for fostering students' CIL (Eickelmann 2011; Gerick et al. 2017; Lorenz et al. 2015). In the following, a distinction is made between the findings regarding the antecedents (cf. "School-level antecedents" section) and process variables (cf. "Process factors on school level" section).

\section{School-level antecedents}

In the light of the national and international research findings, the availability of ICT resources (cf. "Availability of school IT-resources" section), teachers' attitudes towards teaching and learning with ICT (cf. "Attitudes of teachers towards the potentials of ICT for teaching and learning" section), as well as their self-efficacy (cf. "Teachers' ICTrelated self-efficacy" section) towards working with ICT in school emerged to be substantially relevant. Corresponding research findings are summarized in the subsequent sections. 


\section{Availability of school IT-resources}

Although there is consensus among researchers that providing schools with ICT resources is not enough to enhance teaching and learning with ICT (cf. Lai 2008; Law et al. 2008 for findings from the IEA-SITES 2006 Study), a substantial body of research in the field has shown that the availability and appropriateness of ICT for teaching and learning purposes is - trivially-an essential prerequisite for the use of ICT in school (Eickelmann et al. 2017; European Commission 2013; Petko et al. 2016).

\section{Attitudes of teachers towards the potentials of ICT for teaching and learning}

Several international studies have shown that teachers' attitudes towards the potentials of ICT for teaching and learning are a relevant factor for the implementation and/or use of ICT for teaching (Aesaert et al. 2015; Ainley 2018; Buabend-Andoh 2012; Drossel et al. 2016; Hatlevik and Hatlevik 2018; Petko et al. 2018; Tomczyk et al. 2015; Tondeur et al. 2017; Yang and Leung 2015). Especially for Germany there are many indications of the importance of teachers' attitudes and beliefs with regard to ICT in teaching and learning. In this context, IEA-ICILS 2018 was able to show that the majority of eighth-grade teachers in Germany reports "a positive perspective on the use of ICT for instruction" and that the corresponding proportion of teachers was partly substantially larger in all other participating countries (Drossel et al. 2019). Eickelmann and Vennemann (2017) found that the attitudes of teachers are-directly or indirectly-related to the use of ICT in teaching in a selection of European educational systems.

\section{Teachers' ICT-related self-efficacy}

Another relevant antecedent on the school level is the ICT-related self-efficacy of teachers. In this context, international studies have repeatedly pointed to the importance of (self-reported) competences in using ICT (cf. Hatlevik 2017; Saudelli and Ciampa 2016). However, international comparisons revealed, that teachers' attitudes to teaching and learning with ICT are subject to variation-at least in those educational systems participating in IEA-ICILS 2018 (Fraillon et al. 2019a).

\section{Process factors on school level}

In the subsequent sections of this paper, research findings on relevant process factors on school level are presented. The effects of the use of ICT for teaching and learning (cf. 3.2.1), fostering CIL (cf. 3.2.2), and the extent to which teachers at schools cooperate (cf. 3.2.3) are examined in detail.

\section{Use of ICT for teaching and learning}

One main finding of IEA-ICILS 2018 is that teachers' ICT use for teaching and learning is subject to substantial variation. For example, teachers in Germany use ICT significantly less often for classroom instruction than teachers from the most other participating educational systems in IEA-ICILS 2018. About sixty percent of the population of eighth-grade teachers in Germany reports that they ICT at least once a week for classroom instruction. Only in North Rhine-Westphalia and Uruguay is the 
percentage even lower, whereas in most other participating countries there are significantly higher proportions with regard to at least weekly use (cf. Fraillon et al. 2019a).

\section{Fostering ClL in schools}

The acquisition of computer and information literacy can be promoted through various measures on the school level. In this context, some studies draw attention on the assumption that one important school characteristic seems to be the role and the commitment of principals (Dexter 2018; Eickelmann 2011; Gerick 2018). They are mainly involved in creating and supporting learning environments in schools and are able to foster the implementation of ICT, for example by introducing a common school vision and goals (Ottestad 2013), specific educational strategies (Eickelmann et al. 2017), or general educational policies and curricula for the use of ICT in teaching and learning (Biagi and Loi 2013).

\section{Teacher cooperation}

As for other subject domains (e.g. reading or mathematics; cf. Bottia et al. 2016; Ronfeldt and Owens 2015), it could be shown that the extent to which teachers cooperate in school is a relevant factor for both the use of ICT in teaching and learning and fostering students' achievement (Kiru 2018). In this context, several studies have found that teacher cooperation in general can be intensified through the use of ICT and that more intensive forms of teacher cooperation can have a positive effect on teachers' use of ICT for teaching and learning (cf. Drossel and Eickelmann 2017; Tondeur et al. 2012). Despite of the positive effects attributed to teacher cooperation for teaching and learning with ICT at school, the findings of IEA-ICILS 2018 were able to show that teacher cooperation is subject to variation with respect to two aspects (cf. Fraillon et al. 2019a), the first of which is the overall extent to which teacher cooperation occurs varies considerably in the countries participating in IEA-ICILS 2018. In this context, the extent of ICT-related teacher cooperation is highest in countries such as Kazakhstan and lowest in the educational systems of the Republic of Korea, North Rhine-Westphalia, and Germany (ibid.). Furthermore, Fraillon et al. (2014) observed substantial differences in the frequency of cooperation between teachers regarded to be so-called frequent users of ICT in comparison to those who report to be infrequent users. Here, in each of the participating countries of ICILS teachers who are regarded to be frequent ICT users reported significantly higher levels of ICT-related teacher cooperation than teachers who consider themselves to be rare ICT users.

In summary, the presented findings highlight the fact that empirical research has already focused on the relevance of school characteristics for the implementation of ICT in teaching and learning and for fostering students' competent use of ICT. At the same time, the presented studies did not assess the schools' level of CIL and therefore cannot be used to evaluate the existence of organizationally resilient schools in this domain. This information gap is closed by the aforementioned ICILS 2018 study, which assessed eighth-graders' CIL in a computer-based test environment (cf. Fraillon 2018) in an international comparison of 14 participating educational systems, enabling the research questions presented in the subsequent section to be addressed. 
Research questions: Characteristics of unexpectedly successful schools in an international comparison

Based on the relevance of school characteristics for unexpectedly high achieving-or socalled organizationally resilient-schools in the digital age, this paper focuses on the following research questions:

1. Is it possible to identify schools in IEA-ICILS 2018, which, in spite of their challenging socioeconomic student composition, show a high average student achievement in CIL (organizationally resilient schools)?

2. Can these organizationally resilient schools be allocated to a typology of school types based on their school characteristics?

3. If a typology is plausible, how are the identified school-types of those organizationally resilient schools distributed in each of the participating countries and benchmarking participants of IEA-ICILS 2018?

In accordance with the contextual model of the ICILS 2018 study, these research questions focus on the school and/or teacher level and include antecedents as well as process factors (cf. "Review of relevant literature and research questions" section and/or Fraillon et al. 2019b).

\section{Data and methodology}

In the following sections of this paper, the methodical aspects will be addressed in detail. First, the sampling procedures of IEA-ICILS 2018 will be presented (cf. "Sampling procedures in IEA-ICILS 2018" section). Afterwards, the used data, values, and the methodological strategy of this paper will be addressed (cf. "Database, methodology and analytic strategy" section).

\section{Sampling procedures in IEA-ICILS 2018}

The above-mentioned research questions will be answered by a secondary analysis based on the IEA-study IEA-ICILS 2018 (Eickelmann et al. 2019). IEA-ICILS 2018 provides for the second time internationally comparable data of grade eight students' computerrelated competences by assessing students' CIL via computer-based assessment and via administering background questionnaires for students, teachers, principals, and the so-called ICT coordinator in order to assess the conditions of students' CIL acquisition (cf. Fraillon et al. 2019a). Technically, the sampling routine in IEA-ICILS 2018 can be described as multistage stratified cluster sample, which provides a representative cross-section of eight-grade students and their teachers teaching in all 14 participating countries or benchmarking participants (cf. Table 1 and Fraillon et al. 2015; Jung and Carstens 2015).

\section{Database, methodology and analytic strategy Identifying organizationally resilient schools in IEA-ICILS 2018}

In order to answer the first research question on the existence of organizational resilience in the CIL domain, both the average level of the CIL of grade eight students as 
Table 1 Summary of sample sizes (N) differentiated by group of persons and education system

\begin{tabular}{lccc}
\hline Educational systems & \multicolumn{2}{l}{ Sample size } & \\
\cline { 2 - 4 } & Students & Teachers & Schools \\
\hline Chile & 3092 & 1686 & 175 \\
Denmark & 2404 & 1118 & 143 \\
Finland & 2546 & 1853 & 143 \\
French & 2940 & 1462 & 150 \\
Germany & 3655 & $2328^{*}$ & 210 \\
Italy & 2810 & 1775 & 146 \\
Kazakhstan & 3371 & 2623 & 179 \\
Luxembourg & 5401 & 494 & 35 \\
Moscow (Russian Federation) & 2852 & 2235 & 150 \\
North Rhine-Westphalia (Germany) & 1991 & 1468 & 110 \\
Portugal & 3221 & 2823 & 215 \\
Korea, Republic of & 2875 & 2127 & 150 \\
Uruguay & 2613 & 1320 & 158 \\
United States & $6790^{*}$ & $3218^{*}$ & 261 \\
Total & 46,561 & 26,530 & 2225 \\
\hline
\end{tabular}

The benchmark participants are written in cursive

* The IEA minimum participation criteria for the corresponding subsample have not been met (c.f. Fraillon et al. 2019a)

a result of the computer-based assessment (5 plausible values) and the background information on students' socioeconomic status (SES) as assessed by the student questionnaire (HISEI, cf. Ganzeboom et al. 1992) are used. Although in ICILS 2018 several indicators for students' home environment are provided-such as the number of books at home or the highest parental educational-these can be regarded as indicators for the cultural capital of a family which in fact are highly correlated with students' socioeconomic status. However, in order to assess the socioeconomic background of a student's family, it was decided to use to use the HISEI as it can be regarded as an international comparable measure of student's socioeconomic situation.

For the purpose of identifying organizationally resilient schools, the first step was to aggregate the students' individual data (CIL and HISEI) on the school level in order to determine the average achievement level and the average SES of the school. The ranges of these aggregated CIL and HISEI scores were divided by country into three equally wide ranges. In a second step, these schools were regarded as organizationally resilient, if they originate from the lower third of the HISEI spectrum and at the same time belong to the upper third of the CIL spectrum of their countries. With this approach these schools are identified whose students score high on the achievement scale and the same time have a challenging socioeconomic student body composition as assessed by the internationally comparable HISEI measure. Following the terminology presented in "Introduction: The relevance of the school context for a successful implementation of ICT in schools" section of this paper, these schools can be assumed to be organizationally resilient. 


\section{Determining a typology of organizationally resilient schools in IEA-ICILS 2018}

The second research question aims to develop a typology of resilient schools based on school characteristics. Therefore, a latent profile analyses (LPA; cf. Gibson 1959) with school characteristics is conducted utilizing data collected from the IEA-ICILS 2018 teacher questionnaire. LPAs belong to the structure detecting methods in social sciences and their aim is to allocate objects (in this contribution: schools) into clusters according to the similarities in those variables under research. The main advantage of this method is that researchers do not necessarily need pre-experimental hypotheses about the numbers of clusters derived from the analysis as a decision about the optimal number of clusters can be made referring to so called information criteria. For determining an appropriate group solution, information-based criteria such as the Bayes information criterion (BIC, cf. Schwarz 1978) were used in this contribution and tested against LPA models differentiating between two and nine school types (cf. "Results for the second research question: typology of resilient schools in IEA-ICILS 2018" section).

In preparation for the analysis, information on six selected school and teacher characteristics on the school level (cf. Table 2), provided in the teacher questionnaire, were aggregated as the average proportion of teachers who have checked the highest response category of the corresponding item. In detail, the items reflect school-specific characteristics that have been shown to be important for the implementation of ICT in teaching and learning (cf. "Review of relevant literature and research questions" section) and are additionally considered in the contextual framework of IEA-ICILS 2018. By means of the LPA conducted with Mplus 7 (Muthén and Muthén 2012), the organizationally

Table 2 School-specific characteristics used to evaluate a typology of resilient schools

\begin{tabular}{|c|c|}
\hline Characteristics & Item formulation and relevant answer categories \\
\hline \multicolumn{2}{|l|}{ School-level antecedents } \\
\hline Availability of IT-resources in school & $\begin{array}{l}\text { To what extent do you agree or disagree with the fol- } \\
\text { lowing statements about the use of ICT in teaching } \\
\text { at your school?-My school has limited connectivity } \\
\text { (e.g. slow or unstable speed) to the Internet (response } \\
\text { category: I totally disagree) }\end{array}$ \\
\hline $\begin{array}{l}\text { Attitudes of teachers towards the potential of ICT for } \\
\text { teaching and learning }\end{array}$ & $\begin{array}{l}\text { To what extent do you agree or disagree with the fol- } \\
\text { lowing statements about using ICT in teaching and } \\
\text { learning at school?-Helps students to consolidate } \\
\text { and process information more effectively (response } \\
\text { category: I totally agree) }\end{array}$ \\
\hline ICT-related self-efficacy of teachers & $\begin{array}{l}\text { How well can you independently deal with the follow- } \\
\text { ing activities on the computer? - Assessing student } \\
\text { learning (response category: I know how to do this.) }\end{array}$ \\
\hline \multicolumn{2}{|l|}{ Process factors on school level } \\
\hline Frequency of ICT use in school & $\begin{array}{l}\text { How often do you use a computer in these settings? At } \\
\text { school when teaching (response category: every day) }\end{array}$ \\
\hline $\begin{array}{l}\text { Role of fostering students' computer and information } \\
\text { literacy in school }\end{array}$ & $\begin{array}{l}\text { In your teaching of the reference class in this school } \\
\text { year how much emphasis have you given to devel- } \\
\text { oping the following ICT-based capabilities in your } \\
\text { students? -Evaluating their approach to information } \\
\text { searches (response category: strong emphasis) }\end{array}$ \\
\hline $\begin{array}{l}\text { Extent of teacher cooperation for the improvement of } \\
\text { learning with ICT }\end{array}$ & $\begin{array}{l}\text { To what extent do you agree or disagree with the fol- } \\
\text { lowing practices and principles in relation to the use } \\
\text { of ICT in teaching and learning? I work together with } \\
\text { other teachers on improving the use of ICT in class- } \\
\text { room teaching (response category: I totally agree) }\end{array}$ \\
\hline
\end{tabular}


resilient schools were allocated to similar types based on these items. In order to use a maximum amount of information for the LPA, it was decided to pool the data of those ICILS participants mentioned in Table 1 even if single subpopulations did not meet the IEA sample requirements. Because a weighted solution of the LPA did not converge the reported solution in "Results for the second research question: typology of resilient schools in IEA-ICILS 2018" section of this contribution were estimated without additional school weighting variables while the subsequent descriptive statistics ("Results for the third research question: distribution of school types within the ICILS 2018 participating countries and educational systems" section) were calculated using proper school weights.

\section{Country-wise investigation of the distribution of organizationally resilient school types}

The third and last research question of this paper aims to investigate the distribution of school types of organizationally resilient schools. This analysis will be conducted by the means of descriptive statistics in every participating country and benchmarking participant.

\section{Results: identification and description of organizational resilient schools in the digital age}

In the following section, the results corresponding to the research questions (cf. "Research questions: Characteristics of unexpectedly successful schools in an international comparison" section) will be presented. In doing so, the identification of organizationally resilient schools in the domain of CIL will be conducted (cf. "Results towards the first research question: identification of resilient schools in IEA-ICILS 2018" section). Afterwards the second research question will be focused on and the results of a school typology of organizationally resilient schools in IEA-ICILS 2018 will be presented (cf. "Results for the second research question: typology of resilient schools in IEA-ICILS 2018 " section) as well as the descriptive results for research question three concerning the country-wise distribution of those school types identified within research question 2 (cf. "Results for the third research question: distribution of school types within the ICILS 2018 participating countries and educational systems" section).

\section{Results towards the first research question: identification of resilient schools} in IEA-ICILS 2018

As described in "Introduction: The relevance of the school context for a successful implementation of ICT in schools" section, organizationally resilient schools are characterized by originating from the lower third of the HISEI spectrum but achieving a high level of CIL despite their challenging school body composition. Table 3 summarizes the distribution of organizationally resilient schools depending on the participating country of IEA-ICILS 2018.

The results show that across the fourteen educational systems under research 5.3 percent of the schools can be identified as organizationally resilient. However, the proportions of resilient schools vary considerably within the educational systems. In Kazakhstan, Luxembourg and Mocow, for instance, none of schools can be regarded as organizationally resilient while the corresponding proportion in Finland is 17.0 percent. 
Table 3 Proportion of organizationally resilient and non-resilient schools in IEAICILS 2018 (sorted in descending order according to the proportion of resilient schools)

\begin{tabular}{|c|c|c|c|c|c|}
\hline \multirow[t]{2}{*}{ Participant } & \multirow{2}{*}{$\begin{array}{l}\text { Total } \\
\text { (N) }\end{array}$} & \multicolumn{2}{|c|}{ Low HISEI } & \multirow[t]{2}{*}{ Medium HISEI } & \multirow[t]{2}{*}{ High HISE } \\
\hline & & Resilient & Non-resilient & & \\
\hline Finland & 143 & 17.0 & 18.9 & 49.8 & 14.3 \\
\hline France & 150 & 14.4 & 26.6 & 44.2 & 14.9 \\
\hline Portugal & 215 & 10.6 & 27.6 & 46.4 & 15.4 \\
\hline Denmark & 143 & 7.5 & 12.8 & 60.3 & 19.4 \\
\hline Italy & 146 & 7.4 & 25.8 & 57.2 & 9.6 \\
\hline Germany & 210 & 6.0 & 39.5 & 40.2 & 14.2 \\
\hline Uruguay & 158 & 3.7 & 36.7 & 37.3 & 22.3 \\
\hline Korea, Republic of & 150 & 3.5 & 26.4 & 52.3 & 17.7 \\
\hline North Rhine-Westphalia (Germany) & 110 & 2.0 & 44.9 & 33.1 & 20.1 \\
\hline United States & 261 & 1.3 & 20.0 & 52.0 & 26.6 \\
\hline Chile & 175 & 0.7 & 32.5 & 54.6 & 12.2 \\
\hline Kazakhstan & 179 & 0.0 & 17.0 & 73.7 & 9.3 \\
\hline Luxembourg & 35 & 0.0 & 56.6 & 27.1 & 16.3 \\
\hline Moscow (Russian Federation) & 150 & 0.0 & 14.9 & 48.9 & 36.2 \\
\hline Total & 2225 & 5.3 & 28.6 & 48.4 & 17.8 \\
\hline
\end{tabular}

Differences to $100 \%$ are justified in the rounding process

Table 4 Descriptive statistics of those school characteristics used to develop a typology of resilient schools in IEA-ICILS 2018 (aggregated data from the teacher questionnaire)

\begin{tabular}{|c|c|c|c|c|c|}
\hline Characteristic & Mean & Median & SD & MIN & MAX \\
\hline \multicolumn{6}{|l|}{ School-level antecedents } \\
\hline Availability of IT-resources in school & 13.4 & 7.7 & 15.3 & 0.0 & 50.0 \\
\hline $\begin{array}{l}\text { Attitudes of teachers towards the potential of ICT for teaching and learn- } \\
\text { ing }\end{array}$ & 87.5 & 90.5 & 12.3 & 50.0 & 100.0 \\
\hline ICT-related self-efficacy of teachers & 75.8 & 77.4 & 18.2 & 14.3 & 100.0 \\
\hline \multicolumn{6}{|l|}{ Process factors on school level } \\
\hline Frequency of ICT use in school & 47.8 & 50.0 & 22.1 & 0.0 & 100.0 \\
\hline Role of fostering students' computer and information literacy in school & 30.3 & 28.6 & 18.9 & 0.0 & 85.7 \\
\hline Extent of teacher cooperation for the improvement of learning with ICT & 58.4 & 60.0 & 18.8 & 0.0 & 100.0 \\
\hline
\end{tabular}

Additionally, Table 3 shows that resilient schools are underrepresented compared to other schools from the lower HISEI spectrum (non-resilient) in each educational system under consideration. All-over, 107 organizationally resilient schools were identified, which are focused in the subsequent analysis toward a school typology of organizationally resilient schools.

Results for the second research question: typology of resilient schools in IEA-ICILS 2018 In order to prepare the analysis for common characteristics of the resilient schools, Table 4 summarizes descriptive statistics for those items used from the teacher questionnaire, which are subsequently used to develop the mentioned typology (cf. Table 4).

The results show that all variables in total have enough variation for the analysis. In order to answer the second research question and to determine a typology of resilient schools in IEA-ICILS 2018, LPAs with different numbers of types were calculated 
Table 5 Summary of the model fit of the LPAs with different numbers of school profiles (selected group solution highlighted in italics)

\begin{tabular}{llllll}
\hline Group solution & Parameter & AIC & BIC & BIC $_{\text {sample }}$ & Entropy \\
\hline 2-Group solution & 19 & 4986.547 & 5035.662 & 4975.662 & 0.955 \\
3-Group solution & 26 & 4946.487 & 5013.696 & 4931.592 & 0.967 \\
4-Group solution & 33 & 4930.816 & 5016.120 & 4911.911 & 0.898 \\
5-Group solution & 40 & 4913.296 & 5016.694 & 4890.380 & 0.974 \\
6-Group solution & 47 & 4882.271 & 5003.765 & 4855.346 & 0.963 \\
7-Group solution & 54 & 4863.541 & 5003.130 & 4832.606 & 0.935 \\
8-Group solution & 61 & 4842.006 & 4999.689 & 4807.060 & 0.934 \\
9-Group solution & 68 & 4822.503 & 4998.281 & 4783.547 & 0.951 \\
\hline
\end{tabular}

AIC Akaike-information-criterion, $B I C$ Bayes-information-criterion, $B I C_{\text {sample }}$ sample size adjusted BIC

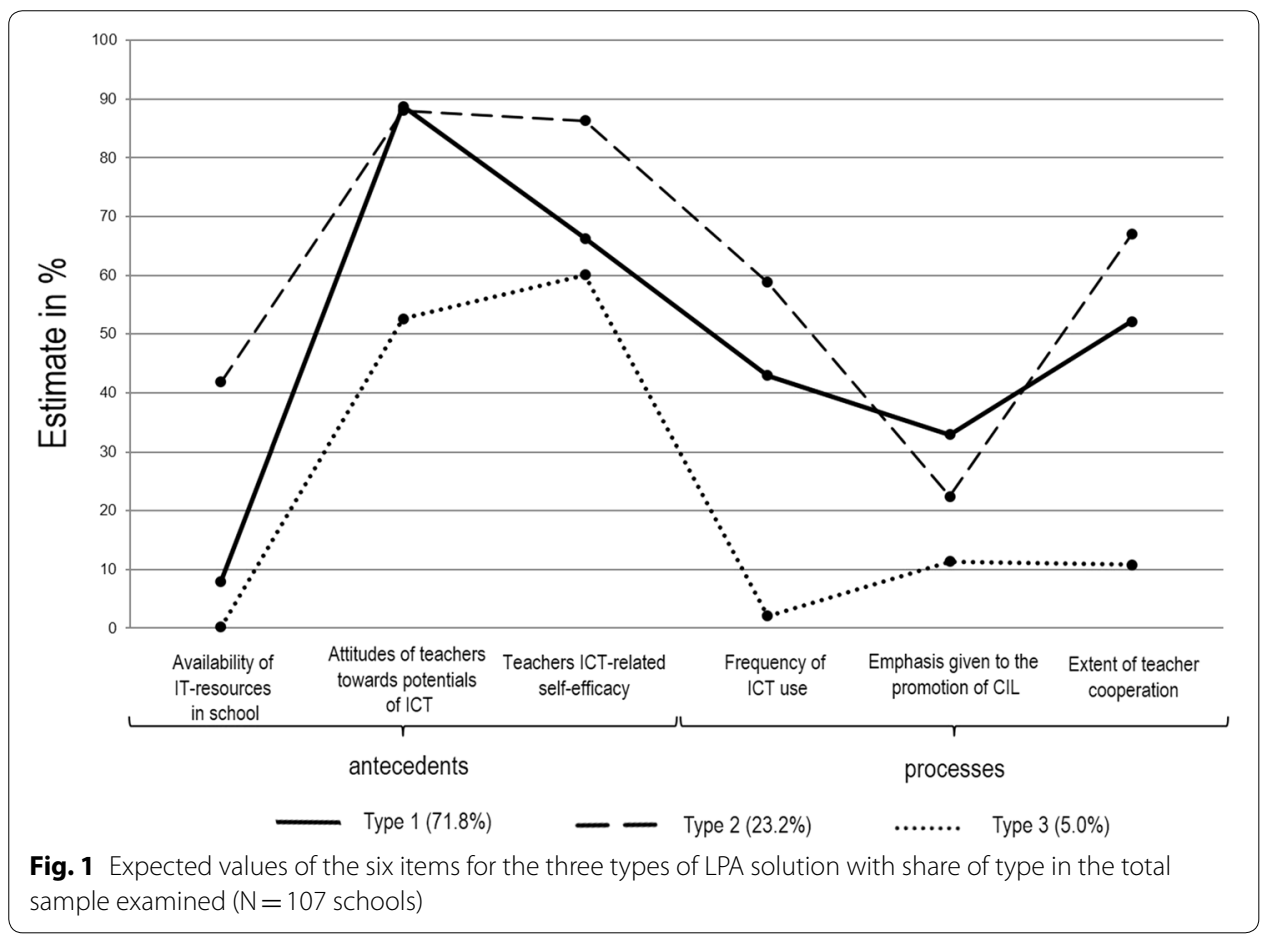

with Mplus7. In order to select the most suitable group solution for the data, socalled information criteria (BIC, AIC, BIC Sample; $_{\text {; }}$. "Results for the second research question: typology of resilient schools in IEA-ICILS 2018" section) were used, which enables to determine the global model fit within the latent profile framework. Table 5 compares the model fit for models with a varying number of assumed school types.

Following the principle of model-parsimony we decided to choose the 3-groupsolution which is characterized by a relatively low BIC and at the same time by a high entropy which is a measure of classification quality and values approaching one indication a clear delineation of profiles (Celeux and Soromenho 1996). Hence a threegroup solution is the choice for all subsequent analyses in this paper. Content wise, these schools have distinctive characteristics, which are displayed in Fig. 1. In the 
next paragraph these school-types will be described in depth according to the average response pattern of the eight grade teachers who teach at these schools.

School type l: "Competent schools with lack of ICT resources" (71.8\% of all resilient schools)

School type I includes over 70 percent of all resilient schools from the eleven considered education systems. The main characteristics of this school type are the high extent of positive attitudes of teachers towards potentials of ICT concerning the antecedents and the high extent of emphasis given to the promotion of CIL on the processes level. What is striking, however, is the low proportion of teachers who disagree that the school has limited connectivity to the Internet (cf. Fig. 1).

\section{School type II: "Competent schools" (23.2\% of all resilient schools)}

Less than a quarter $(23.2 \%)$ of all organizationally resilient schools can be classified as being competent schools (school type II). These schools can be characterized by high amounts concerning the availability of ICT resources, teachers' attitudes towards the potentials of ICT and teachers ICT related self-efficacy on the level of the antecedents. Moreover, the extent regarding the process-related items are also comparatively high. For example, nearly 60 percent of the teachers use ICT at school when teaching every day. It is also striking that the lack of ICT resources is the highest compared to the other two types.

\section{School type III: "Restrained schools" (5.0\% of all resilient schools)}

None of the teachers at resilient schools allocated to the "Restrained schools" school type, disagree with the statement that the school has limited connectivity to the Internet, which means that there is a lack concerning the internet connection. The values for the other two factors at process level are also the lowest compared to the other two types. Moreover, the extent of the process-related aspects is comparatively small. For example, less than 5 percent of the teachers use ICT every day.

Results for the third research question: distribution of school types within the ICILS 2018 participating countries and educational systems

As mentioned in "Research questions: Characteristics of unexpectedly successful schools in an international comparison" section the third research question of this contribution is to investigate the distribution of organizationally resilient school types in those countries under research. Because in Kazakhstan, Luxembourg, and Moscow (Russian Federation) no resilient schools could be identified, they will not further be addressed in the present section.

Table 6 summarizes the relative frequencies of school types I to III in those 11 countries where organizationally resilient schools could be identified.

As can be obtained from Table 6, the distribution of school types is subject to considerable variation in those countries under research. In Italy, North Rhine-Westphalia, and Uruguay only school type I "Competent schools with lack of ICT resources" could be identified among the organizationally resilient schools. Apart from Chile (26.6\%) and Denmark (49\%), the proportions in this type also exceed 50 percent in the other countries. School type II (competent schools) is particularly found in Chile (73.4\%) and the 
Table 6 Distribution of resilient school types in those participating countries and benchmark participants of IEA-ICILS 2018 where organizationally resilient schools could be identified

\begin{tabular}{|c|c|c|c|c|c|c|}
\hline & \multicolumn{2}{|c|}{ School type I } & \multicolumn{2}{|c|}{ School type II } & \multicolumn{2}{|c|}{ School type III } \\
\hline & $\%$ & (SE) & $\%$ & (SE) & $\%$ & (SE) \\
\hline Chile & 26.6 & $(75.0)$ & 73.4 & $(75.0)$ & 0.0 & $(0.0)$ \\
\hline Denmark & 49.0 & $(16.6)$ & 13.7 & $(11.4)$ & 37.3 & $(18.6)$ \\
\hline Finland & 69.5 & $(11.0)$ & 30.5 & $(11.0)$ & 0.0 & $(0.0)$ \\
\hline France & 93.1 & $(7.0)$ & 6.9 & $(7.0)$ & 0.0 & $(0.0)$ \\
\hline Germany & 63.5 & $(15.0)$ & 19.1 & $(12.2)$ & 17.5 & $(11.5)$ \\
\hline Italy & 100.0 & $(0.0)$ & 0.0 & $(0.0)$ & 0.0 & $(0.0)$ \\
\hline Korea, Republic of & 57.0 & $(26.1)$ & 43.0 & $(26.1)$ & 0.0 & $(0.0)$ \\
\hline North-Rhine Westphalia & 100.0 & $(0.0)$ & 0.0 & $(0.0)$ & 0.0 & $(0.0)$ \\
\hline Portugal & 79.9 & $(11.6)$ & 20.1 & $(11.6)$ & 0.0 & $(0.0)$ \\
\hline Uruguay & 100.0 & $(0.0)$ & 0.0 & $(0.0)$ & 0.0 & $(0.0)$ \\
\hline USA & 51.0 & $(27.3)$ & 49.0 & (27.3) & 0.0 & $(0.0)$ \\
\hline Total & 71.8 & (8.1) & 23.2 & (7.9) & 5.0 & (2.0) \\
\hline
\end{tabular}

USA (49.0\%), whereas this type of school does not occur in Italy, North-Rhine Westphalia and Uruguay. School type 3 is only found in Denmark (18.6\%) and Germany (17.5\%). It also becomes apparent, that only in two participating countries all three school types seem to be represented (Denmark and Germany).

\section{Discussion}

Through a secondary analysis of the IEA-ICILS 2018 database, the research questions, as to whether the phenomenon of organizationally resilient schools can also be observed in the domain of CIL (research question 1) and whether these resilient schools can be grouped into certain school types that can be described with similar school characteristics were answered (research question 2). The last research question of the contribution aimed to investigate the distribution of those school types identified by the LPA in the educational systems where organizationally resilient schools could be located (research question 3).

Overall, about one twentieth of the schools participating in IEA-ICILS 2018 in these selected countries can be regarded as successful in spite of their socioeconomically challenged student body composition and thus fulfil the requirements for being so-called organizationally resilient (research question 1). In this context, the lowest proportion of resilient schools was observed in Kazakhstan, Luxembourg, and Moscow, whereas in Finland almost every fifth school can be regarded as being organizationally resilient.

The findings of the second research question demonstrate that it is possible to allocate organizationally resilient schools to school types based on their school characteristics. In this context, the results of the analysis indicate, that three specific school types can be identified across all participating IEA-ICILS 2018 countries under research in this contribution: school type I "Competent schools with lack of ICT resources" (71.8\%), school type II "Competent schools" (23.2\%) and school type III "Restrained schools" (5.0\%). 
The results of the third research questions show that the proportion of school types in those educational systems in subject to considerable variation. For example, school type III could only be observed in Denmark and Germany while in all countries at least a considerable amount of schools belong to the type of "Competent schools with lack of ICT resources (school type I) which could be an indication that those characteristics of these schools (high extend of positive attitudes towards ICT and a high self-efficacy towards teaching and learning; cf. "Results for the second research question: typology of resilient schools in IEA-ICILS 2018" section) could be regarded as the motor for organizationally resilience in the domain of CIL. Therefore, the results also illustrate the importance of the European Commission's digital education action plan, which aims to support the digitalization-related competencies of all students in the EU member states (European Commission 2020).

However, the limitations of the presented research lie in the cross-sectional design of IEA-ICILS 2018. Therefore, it is not possible to determine whether the students at resilient schools, despite the schools' student body composition, reach a high level of CIL due to the instructional activities at the school or for other reasons. In addition, from a methodological perspective it is questionable that the criterion of frequent ICT use in schools - which has been used as one criterion of the LPA - could lead to further insights because research shows that it is not only the frequency of ICT use which has an effects on students CIL but especially the qualitative aspects of teachers ICT use in schools. In this context, it is debatable whether the criterion of frequency of ICT use or qualitative aspects of teachers' ICT use for teaching and learning would lead to different results. Overall, the results presented in this paper underpin the importance of international comparisons for answering questions regarding current developments and causal interference in the CIL domain, and underline the necessity of qualitative-and not only quantitative-measures of ICT use in schools which will have to be addressed by future research.

\section{Conclusions}

Given the increasing importance of students ability to use ICT and digital information in a competent manner, this paper focused on so-called organizationally resilient schools with regard to the domain of CIL. These schools are simultaneously characterized by a high level of student competences and a challenged student body composition in terms of the average socioeconomic status. The international comparison permits the conclusion that the phenomenon of organizational resilience is also current prevalent in the domain of CIL and that the occurrence of resilient schools is subject to variation in the selected education systems participating in IEA-ICILS 2018.

The significance of the study lies particularly in the fact that it could be shown that there are schools with a challenging student composition, in which the students nevertheless acquire above-average computer and information literacy. It was also shown what school characteristics the schools concerned have. The analyzes have thus laid the foundation stone for a more in-depth examination of the general school conditions under which the students acquire competencies in this relevant field. 


\section{Abbreviations}

CIL: computer and information literacy; HISEl: intrument employed to assess the students' socioeconomic status; IEA: International Association for the Evaluation of Educational Achievement; ICILS 2013; 2018: International Computer and Information Literacy Study 2013 and 2018; ICT: information and communications technology; SER: school effectiveness research; LPA: latent profile analyses; SES: students'socioeconomic status.

\section{Acknowledgements}

None.

\section{Authors' contributions}

All authors made a substantial contribution to the conception and design, as well as to the analysis and interpretation of results. They were jointly responsible for drafting and revising the article. All authors read and approved the final manuscript.

\section{Authors' information}

Kerstin Drossel, Dr., is a senior researcher at the Institute for Educational Science at Paderborn University. Her main research interests include school development research, teacher profession(alism), and social disparities. She is part of the national project team for the International Computer and Information Literacy Study (ICILS 2018) in Germany.

Birgit Eickelmann, Dr., is professor for School Education at the Institute for Educational Science at Paderborn University. Her main research interests include school development research, the use of digital technologies in teaching and learning, and large-scale assessments in the field of education. Currently, she is the National Research Coordinator (NRC) for the International Computer and Information Literacy Study (ICILS 2018) in Germany.

Mario Vennemann, Dr., is a senior researcher at the Institute for Educational Science at Paderborn University. His research interests include empirical large-scale assessments in education, compositional/contextual effects of schools, and various aspects of teaching and learning with information and communication technology (ICT). He is also part of the national project team for the International Computer and Information Literacy Study (ICILS 2018) in Germany.

\section{Funding}

The IEA-ICILS 2018 study was carried out in Germany funded by the BMBF (Federal Ministry of Education and Research).

\section{Availability of data and materials}

The datasets generated and/or analysed during the current study are not publicly available due [The data materials of the IEA-ICILS 2018 study will be published this year] but are available from the corresponding author on reasonable request.

\section{Competing interests}

The authors declare that they have no financial or non-financial competing interests.

Received: 24 February 2020 Accepted: 3 July 2020

Published online: 15 July 2020

\section{References}

Aesaert, K., van Braak, J., van Nijlen, D., \& Vanderlinde, R. (2015). Primary school pupils ICT competences: Extensive model and scale development. Computers \& Education, 81, 326-344.

Ainley, J. (2018). Students and their computer literacy: Evidence and curriculum implications. In J. Voogt, G. Knezek, R. Christensen, \& K.-W. Lai (Eds.), Second handbook of information technology in primary and secondary education (pp. 69-88). Cham: Springer.

Ainley, J., Schulz, W. \& Fraillon, J. (2016). A global measure of digital and ICT literacy skills. In Background paper prepared for the 2016 Global Education Monitoring Report. Paris: UNESCO.

Biagi, F., \& Loi, M. (2013). Measuring ICT use and learning outcomes. Evidence from recent econometric studies. European Journal of Education, 48(1), 28-42.

Bottia, M. C., Valentina, L., Moller, S., Mickelson, R. A., \& Stearns, E. (2016). Teacher collaboration and Latinos/as' mathematics achievement trajectories. American Journal of Education, 122(4), 505-535.

Buabend-Andoh, C. (2012). Factors influencing teachers' adoption and integration of information and communication technology into teaching: A review of the literature. International Journal of Education and Development using Information and Communication Technology, 8(1), 136-155.

Carretero, S., Vuorikari, R., \& Punie, Y. (2017). DigComp 2.1. The digital competence framework for citizens with eight proficiency levels and examples of use. Luxembourg: Publications Office of the European Union.

Celeux, G., \& Soromenho, G. (1996). An entropy criterion for assessing the number of clusters in a mixture model. Journal of Classification, 13, 195-212.

Creemers, B. P. M., \& Kyriakides, L. (2006). Critical analysis of the current approaches to modelling educational effectiveness: The importance of a dynamic Model. School Effectiveness and School Improvement, 17(3), 347-366.

De Jong, R., Westerhof, K. J., \& Kruiter, J. H. (2004). Empirical evidence of a comprehensive model of school effectiveness: A multilevel study in mathematics in the 1st year of junior general education in the Netherlands. School Effectiveness and School Improvement, 15(1), 3-31.

Dexter, S. (2018). The role of leadership for information technology in education: systems of practices. In J. Voogt, G. Knezek, R. Christensen, \& K.-W. Lai (Eds.), Second handbook of information technology in primary and secondary education (pp. 483-498). Cham: Springer. 
Drossel, K., \& Eickelmann, B. (2017). Teachers'participation in professional development concerning the implementation of new technologies in class-Different types of teachers and their relationship with the use of computers, ICT selfefficacy and emphasis on teaching ICT. Large-scale Assessments in Education, 5(19), 1-13.

Drossel, K., Eickelmann, B., \& Gerick, J. (2016). Predictors of teachers' use of ICT in school-The relevance of school characteristics, teachers' attitudes and teacher collaboration. Education and Information Technologies, 22(2), 551-573.

Drossel, K., Eickelmann, B., Schaumburg, H. \& Labusch, A. (2019). Nutzung digitaler Medien und Prädiktoren aus der Perspektive der Lehrerinnen und Lehrer im internationalen Vergleich [Use of digital media and predictors from the perspective of teachers in an international comparison]. In B. Eickelmann, W. Bos, J. Gerick et al. (Eds.), ICILS 2018 \#Deutschland. Computer- und informationsbezogene Kompetenzen von Schülerinnen und Schülern im zweiten internationalen Vergleich und Kompetenzen im Bereich Computational Thinking (p. 205-240). Münster, Waxmann.

Eickelmann, B. (2011). Supportive and hindering factors to a sustainable implementation Im ICT in schools. Journal for Educational Research Online, 3(1), 75-103.

Eickelmann, B. (2018). Cross-national policies on information and communication technology in primary and secondary schools: An international perspective. In J. Voogt, G. Knezek, R. Christensen, \& K.-W. Lai (Eds.), Springer international handbooks of education second handbook of information technology in primary and secondary education (pp. 1227-1238). Cham: Springer.

Eickelmann, B., Bos, W., Gerick, J., Goldhammer, F., Schaumburg, H., Schwippert, K., et al. (Eds.). (2019a). ICILS 2018 \#Deutschland - Computer- und informationsbezogene Kompetenzen von Schülerinnen und Schülern im zweiten internationalen Vergleich und Kompetenzen im Bereich Computational Thinking. Waxmann: Münster.

Eickelmann, B., Gerick, J., \& Koop, C. (2017). ICT use in mathematics lessons and the mathematics achievement of secondary school students by international comparison: Which role do school level factors play? Journal for Education and Information Technologies, 22(4), 1527-1551.

Eickelmann, B., Gerick, J., \& Vennemann, M. (2019b). Unerwartet erfolgreiche Schulen im digitalen Zeitalter-Eine Analyse von Schulmerkmalen resilienter Schultypen auf Grundlage der IEAStudie ICILS 2013 [Unexpectedly successful schools in the digital age-An analysis of school characteristics of resilient school types based on the IEA study ICILS 2013]. Journal for Educational Research Online, 11(1), 118-144.

Eickelmann, B., \& Vennemann, M. (2017). Teachers'attitudes and beliefs regarding ICT in teaching and learning in European countries. European Educational Research Journal, 16(6), 733-761.

Ercikan, K., Asil, M., \& Grover, R. (2018). Digital divide: A critical context for digitally based assessments. Education Policy Analysis Archives, 26(51), 1-24.

European Commission (2013). Survey of schools: ICT in education. Benchmarking access, use and attitudes to technology in Europe's schools. Luxemburg: Publications Office of the European Union.

European Commission (2020). Digital Education Action Plan. https://ec.europa.eu/education/education-in-the-eu/digitaleducation-action-plan_en. Accessed 21 February 2020.

Ferrari, A. (2012). Digital competence in practice: An analysis of frameworks. Brussels: Publication Office of the European Commission.

Fraillon, J. (2018). International large-scale computer-based studies on information technology literacy in education. In J. Voogt, G. Knezek, R. Christensen, \& K.W. Lai (Eds.), Second handbook of information technology in primary and secondary education (pp. 1161-1180). Cham: Springer.

Fraillon, J., Ainley, J., Schulz, W., Duckworth, D. \& Friedman, T. (2019b). IEA International Computer and Information Literacy Study 20mmm 18: Assessment Framework. Amsterdam: International Association for the Evaluation of Educational Achievement (IEA).

Fraillon, J., Ainley, J., Schulz, W., Friedman, T. \& Duckworth, D. (2019a). Preparing for life in a digital world IEA International Computer and Information Literacy Study 2018 International Report. Amsterdam: International Association for the Evaluation of Educational Achievement (IEA).

Fraillon, J., Ainley, J., Schulz, W., Friedman, T., \& Gebhardt, E. (2014). Preparing for life in a digital age. The IEA International Computer and Information Literacy Study International Report. Melbourne: Springer.

Fraillon, J., Schulz, W., Friedman, T., Ainley, J., \& Gebhardt, E. (Eds.). (2015). ICILS 2013 Technical Report. Amsterdam: Springer.

Ganzeboom, H. B. G., De Graaf, P. M., \& Treiman, D. J. (1992). A standard international socio-economic index of occupational status. Social Science Research, 21(1), 1-56.

Geisinger, K. F. (2016). 21st century skills: what are they and how do we assess them? Applied Measurement in Education, 29(4), 245-249.

Gerick, J. (2018). School level characteristics and students' CIL in Europe—A latent class analysis approach. Computers \& Education, 120, 160-171.

Gerick, J., Eickelmann, B., \& Bos, W. (2017). School-level predictors for the use of ICT in schools and students' CIL in international comparison. Large-scale Assessments in Education, 5(1), 1-13.

Gibson, W. A. (1959). Three multivariate models: Factor analysis, latent structure analysis, and latent profile analysis. Psychometrika, 24(3), 229-252.

Hatlevik, O. E. (2017). Examining the relationship between teachers'self-efficacy, their digital competence, strategies to evaluate information, and use of ICT at school. Scandinavian Journal of Educational Research, 61(5), 555-567.

Hatlevik, I. K., \& Hatlevik, O. E. (2018). Examining the relationship between teachers'ICT self-efficacy for educational purposes, collegial collaboration, lack of facilitation and the use of ICT in teaching practice. Frontiers in Psychology, 9(1), 1-8.

Hatlevik, O. E., Ottestad, G., \& Throndsen, I. (2015). Predictors of digital competence in 7th grade: a multilevel analysis. Journal of Computer Assisted Learning, 31(3), 220-231.

Jung, M., \& Carstens, M. (2015). ICILS 2013 User Guide for the International Database. Amsterdam: Springer.

Kiru, E. W. (2018). Mathematics teachers'use of information and communication technologies: An international comparison. International Journal of Research in Education and Science, 4(1), 165-177.

Lai, K.-W. (2008). ICT supporting the learning process: The premise, reality, and promise. In J.Voogt \& G. Knezek (Eds.), International Handbook of Information Technology in Primary and Secondary Education (pp. 215-230): Springer.

Law, N., Pelgrum, W. J., \& Plomp, T. (Eds.). (2008). Pedagogy and ICT use in schools around the world. Findings from the IEA SITES 2006 Study. Hongkong: Springer. 
Lorenz, R., Eickelmann, B. \& Gerick, J. (2015). What affects students' computer and information literacy around the World? -An analysis of school and teacher factors in high performing countries. In D. Slykhuis \& G. Marks (Eds.), Proceedings of Society for Information Technology \& Teacher Education International Conference 2015(pp. 1212-1219). Chesapeake: AACED.

Meggiolaro, S. (2018). Information and communication technologies use, gender and mathematics achievement: evidence from Italy. Social Psychology of Education, 21(2), 497-516.

Mishra, P., \& Mehta, R. (2017). What we educators get wrong about 21st-century learning: results of a survey. Journal of Digital Learning in Teacher Education, 33(1), 6-19.

Muijs, D., Harris, A., Chapman, C., Stoll, L., \& Russ, J. (2004). Improving schools in socioeconomically disadvantaged areas—A review of research evidence. School Effectiveness and School Improvement, 15(2), 149-175.

Muthén, L. K., \& Muthén, B. O. (2012). Mplus 7. Los Angeles, CA: Muthén \& Muthén.

OECD. (2010). Are the New Millenium Learners Making the Grade? Technology Use and Educational Performance in PISA. Paris: OECD.

Olszewski, B. \& Crompton, H. (2020). Educational technology conditions to support the development of digital age skills. Computers \& Education, 150 (online first).

Ottestad, G. (2013). School leadership for ICT and teachers' use of digital tools. Nordic Journal of Digital Literacy, 8, 107-125.

Ottestad, G., \& Gudmundsdottir, G. B. (2018). Information and communication technology policy in primary and secondary education in Europe. In J. Voogt, G. Knezek, R. Christensen, \& K.-W. Lai (Eds.), Second Handbook of Information Technology in Primary and Secondary Education (pp. 1343-1362). Cham: Springer.

Petko, D., Cantieni, A., \& Prasse, D. (2016). Perceived quality of educational technology matters: A secondary analysis of students' ICT Use, ICT-Related Attitudes, and PISA 2012 test scores. Journal of Educational Computing Research, 54(8), 1070-1091.

Petko, D., Prasse, D., \& Cantieni, A. (2018). The interplay of school readiness and teacher readiness for educational technology integration: A structural equation model. Computers in the Schools, 35(1), 1-18.

Ronfeldt, M., \& Owens, S. (2015). Teacher collaboration in instructional teams and student achievement. American Educational Research Journal, 52(3), 475-514.

Saudelli, M. G., \& Ciampa, K. (2016). Exploring the role of TPACK and teacher self-efficacy: An ethnographic case study of three iPad language arts classes. Technology, Pedagogy and Education, 25(2), 227-247.

Scheerens, J. (1990). School effectiveness research and the development of process indicators for school functioning. School Effectiveness and School Improvement, 1(1), 61-80.

Scheerens, J., \& Bosker, R. J. (1997). The foundations of educational effectiveness. Oxford, UK: Pergamon.

Schelvis, R. M. C., Zwetsloot, G. I. J. M., Bos, E. H., \& Wiezer, N. M. (2014). Exploring teacher and school resilience as a new perspective to solve persistent problems in the educational sector. Teachers and Teaching, 20(5), 622-637.

Schleicher, A. (2018). World Class. How to build a 21st-century school system. Paris: OECD.

Schwarz, G. (1978). Estimating the dimension of a model. The Annals of Statistics, 6(2), 461-464.

Senkbeil, M., Drossel, K., Eickelmann, B. \& Vennemann, M. (2019). Soziale Herkunft und computer- und informationsbezogene Kompetenzen von Schülerinnen und Schülern im zweiten internationalen Vergleich [Social origin and computer and information-related competencies of schoolchildren in a second international comparison]. In B. Eickelmann, W. Bos, J. Gerick, F. Goldhammer, H. Schaumburg, K. Schwippert, M. Senkbeil, J. Vahrenhold (Eds.), ICILS 2018 \#Deutschland. Computer- und informationsbezogene Kompetenzen von Schülerinnen und Schülern im zweiten internationalen Vergleich und Kompetenzen im Bereich Computational Thinking (pp. 301-333). Münster; New York: Waxmann.

Tomczyk, L., Szotkowski, R., Fabiś, A., Wąsiński, A., Chudý, Š., \& Neumeister, P. (2015). Selected aspects of conditions in the use of new media as an important part of the training of teachers in the Czech Republic and Poland—Differences, risks and threats. Education and Information Technologies, 22(3), 747-767.

Tondeur, J., Van Braak, J., Ertmer, P., \& Ottenbreit-Leftwich, A. (2017). Understanding the relationship between teachers'pedagogical beliefs and technology use in education: A systematic review of qualitative evidence. Educational Technology Research and Development, 65(3), 555-575.

Tondeur, J., Van Braak, J., Sang, G., Voogt, J., Fisser, P., \& Ottenbreit-Leftwich., (2012). Preparing pre-service teachers to integrate technology in education: A synthesis of qualitative evidence. Computers \& Education, 59, 134-144.

Tondeur, J., van Keer, H., Van Braak, J., \& Valcke, M. (2008). ICT integration in the classroom: Challenging the potential of a school policy. Computers \& Education, 51, 212-223.

Torney-Purta, J., \& Amadeo, J.-A. (2013). International Large-Scale Assessments: challenges in reporting and potentials for secondary analysis. Research in Comparative and International Education, 8(3), 248-258.

UNESCO Institute for Statistics. (2017). Metadata for the global and thematic indicators for the follow-up and review of SDG 4 and Education 2030. http://gaml.uis.unesco.org/wp-content/uploads/sites/2/2018/10/metadata-global-thematic-indicators -sdg4-education2030-2017-en_1.pdf. Accessed 21 Febuary 2020.

van Deursen, A., \& van Dijk, J. (2018). The first-level digital divide shifts from inequalities in physical access to inequalities in material access. New Media \& Society., 11, 1163.

Voogt, J., Erstad, O., Dede, C., \& Mishra, P. (2013). Challenges to learning and schooling in the digital networked world of the 21st century. Journal of Computer Assisted Learning, 29(5), 403-413.

Voogt, J., Knezek, G., Christensen, R., \& Lai, K.-W. (2018). International handbook of information technology in primary and secondary education (Vol. 2). Cham: Springer.

Yang, X., \& Leung, F. K. S. (2015). The relationships among pre-service mathematics teachers'beliefs about mathematics, mathematics teaching, and use of technology in China. Eurasia Journal of Mathematics, Science \& Technology Education, $11(6), 1363-1378$.

\section{Publisher's Note}

Springer Nature remains neutral with regard to jurisdictional claims in published maps and institutional affiliations. 